\title{
Revisiting and Enlisting Important QTLs Identified in Frech Bean (Phaseolus vulgaris L.): A Review
}

\author{
Sandeep Kaur Dhaliwal ${ }^{1}$, Pooja Salaria ${ }^{2}$ and Prashant Kaushik P.4* $^{3,{ }^{*}}$ \\ ${ }^{1}$ Department of Plant Breeding and Genetics, Punjab Agricultural University, Ludhiana 141004, \\ India \\ ${ }^{2}$ Department of Plant Pathology, Punjab Agricultural University, Ludhiana 141004, India \\ ${ }^{2}$ Instituto de Conservación y Mejora de la Agrodiversidad Valenciana, Universitat Politècnica de \\ València, 46022 Valencia, Spain \\ ${ }^{3}$ Nagano University, 1088 Komaki, Ueda, 386-0031 Nagano, Japan \\ *Correspondance: prakau@doctor.upv.es
}

\begin{abstract}
French bean (Phaseolus vulgaris L.) a member of family Leguminosae is a useful source of protein ( 22\%), minerals (folate), vitamins and fibre. Abiotic and biotic stresses are the constraints to high yield and production of French bean. Varieties reluctant to diseases as well as abiotic stresses is among the top breeding objectives for the French bean. Mendelian ratios could know the genetically reliable forms of resistance, whereas it's more robust to understand the intricate kinds, often referred to as quantitative trait loci (QTL). Here, we review and compile the information from the studies related to the identification of QTLs for critical biofortification traits, biotic and abiotic stresses in French bean. Successful map-based cloning requires QTLs represent single genes which could be isolated in near-isogenic lines, and also the genotypes could be unambiguously inferred by progeny testing. Overall, this information will be useful for directing the French bean breeders to select a suitable method for the inheritance evaluation of quantitative traits and determining the novel genes in germplasm resources to ensure that much more potential of genetic information may be uncovered.
\end{abstract}

Keywords: abiotic stress, biotic stress, biofortification, breeding, French bean, QTLs

\section{Introduction}

French bean (Phaseolus vulgaris L.) is a crucial legume grown globally which is a rich source of protein $(\sim 22 \%)$, minerals (folate), vitamins and fibre (Broughton et al. 2003). The useful products of this legume are snap beans (harvested before seed development), shell beans (harvested at physiological maturity), dry beans (harvested at complete maturity). It is also referred to as common bean, string bean, podded bean etc. The seeds of the snap bean are used in dry static (dry bean type). It is also known as pinto, pink, kidney, small red etc. It is basically cultivated and consumed in countries of Africa, Asia and Latin America. Among these countries, eight out of the top ten are considered to be developing (Gepts et al. 2018). This legume is an important directly consumed legume and improving its vitamin and mineral content can address the malnutrition among the poor population in developing countries (Blair 2013). So, the main focus of breeders is to develop biofortified crops for increasing the concentration of zinc and iron in French bean. Due to domestication of French bean from wild resources which inhabit a narrow ecological niche, the crop faces many challenges of biotic and abiotic stresses within its agroecological zone. 
Biotic stresses include fungus, bacteria, viruses, insects and nematodes, whereas abiotic stress includes heat, drought, cold and deficiency or toxicity of soil nutrient. Farmers having high input can combat these stresses by the application of fertilizers, irrigation and pesticides. However, the utilization of these inputs, reduce the profit rate and pollute the environment. Thus, biotic and abiotic stresses are a major drawback for the production and high yield of French bean. Varieties resistant to diseases and abiotic stresses is among the primary objectives. Cultivars possessing resistance against stress can reduce the use of pesticides and decrease the yield loss from these stresses. Thus, enabling stable production of beans across different environments and diverse soil conditions. The genetically simple forms of resistance can be understood by Mendelian ratios, whereas it is difficult to understand the complex forms, often referred as quantitative trait loci (QTL).

Most of the abiotic and biotic stresses are under the control of complex genomic regions. The various molecular markers throughout the genome and dense molecular maps ( add reference of SSR maker map and SNP marker map) are available which provides an opportunity for identifying the simple Mendelian factors as well as complex quantitative traits (QTLs) governing traits of interest. The favourable and useful QTL and genes for different traits having economic importance are found scattered in both wild and cultivated population in different gene pools of the french bean. Several efforts have been made for integrating the different breeding approaches to broaden the genetic base and introgress the QTL and resistance genes. This review emphasizes on biofortification traits and resistance against biotic and abiotic stresses with a primary focus on research relating to identification of QTLs in French bean.

\section{History}

The backbone of every breeding and QTL mapping study is the availability of desirable sources of variation, which is tracked from its wild relatives or landraces adapted to varying stresses over the evolutionary line. The evolutionary history of French bean is shared by two separate gene pools, i.e. Andean gene pool native to South America. Variation in seed size, plant morphology, seed storage protein content, molecular and biochemical markers has divided two gene pools, giving rise to two independent domestication events of the crop (Singh et al. 1991; Blair et al. 2006). Thus, a range of abiotic and biotic stress resistance and biofortification traits can be extracted from extensively diverse germplasm sources. Disease resistance was found in wild relatives such as $P$. acutifolius (Singh et al. 2001), P. coccineus (Beaver et al. 2005) and $P$. costaricensis (Debouck 1999). whereas P. parvifolius and P. acutifolius were known to harbour high iron content (Sperotto and Ricachenevsky 2017). The two gene pools of French bean are further classified into races based on adaptation, morphology and traits of agronomic importance. The Andean gene pool was subdivided into races Peru, Nueva Granada and Chile, whereas Mesoamerican includes races Durango, Jalisco, Mesoamerica and Guatemala (Singh et al. 1991; Beebe et al. 2000). The information on crossing compatibility and valuable genes present across the range of bean germplasm in various pools is expected to add valuable QTLs to existing molecular tools.

\section{Biofortification}

Consumption of food by poor people is meant to be for bellyful, which brings along deficiency of micronutrients and malnutrition among them as they cannot afford costly 
supplements. Breeders strive for developing biofortified crops, especially to meet the nutritional demands of a vulnerable group of society. French bean cultivars packed with a bunch of micronutrients can help curb malnutrition as its nutritional status is higher than cereals (Broughton et al. 2003). It is a choice of crop for biofortification as its baseline micronutrient content is very high, e.g. Fe content is $55 \mathrm{ppm}$ plus high variability of the traits is present in germplasm (Petry et al. 2015). Germplasm screening of wild and cultivated genotypes resulted in the discovery of lines carrying $110 \mathrm{ppm}$ Fe content. Wild relatives of French bean, i.e. P. dumosus and P. coccineus are known to harbour Fe content as high as 127 ppm (Blair et al. 2013). QTL mapping for Fe and Zn accumulation traits was performed on RILs derived from the cross of 'DOR364' and 'G19833' (Blair et al. 2009).

QTLs in the study mainly clustered on top of B11 linkage group for both the traits, indicating important region expressing micronutrients, whereas minor QTLs on B4, B6, B7 and B8 for iron and B6, B7, and B9 for zinc content. In another study similar results were obtained, RILs originating from cross of AND696 and G19833 were employed in QTL mapping of Fe, Zn, and P levels and co-localized QTLs for Fe and Zn were found on B1, B6, and B11 linkage groups (Cichy et al. 2009b). Blair and Izquierdo, (2012) conducted advanced backcross QTL strategy to introgress Fe and Zn into Andean gene pool cultivar 'Cerinza' from wild genotype (G10022) and simultaneous mapping of traits for iron content in seeds and on b01, b04 and b10 for zinc content. A meta-QTL study performed on seven populations for Zn and Fe content identified 12 meta QTLs among a total of mapped 87 QTLs (Izquierdo et al. 2018). A total of 8 QTLs among 12 identified were co-localized for both traits. Putative candidate gene lying in the vicinity of mapped QTLs include root uptake (FRO, NA and ZIP), translocation in the plant (FRO, MATE, ZIP and NA) and seed storage (NRAMP). Transcriptome sequencing of variant lines for $\mathrm{Zn}$ content using Illumina Genome AnalyzerII revealed three genes were involved in Zn transport i.e. ZIP, ZIF and HMA along with potent SNPs for marker assisted selection (Astudillo-Reyes et al. 2015). The interesting observation in these studies suggest that genes controlling Fe and $\mathrm{Zn}$ in french bean are co-localized, based on their position in genome they could have association with Phaseolin (seed storage protein). On the other hand, Ferretin (iron storage protein) was connected to one the QTL in mapping studies. Thus, such genes could be putative candidates for translation of essential minerals and nutrients.

The goal of improving nutritional status of beans is not only limited to increasing the level of nutrients but also to enhance the absorption of inbuilt nutrition. Phytates present in French bean chelate essential food nutrients. Thus their genetic removal is desirable for health benefits. QTLs linked to phytate content, and its co-related seed phosphorus content was mapped on B5, B6, B7 and B10 linkage group originating from recombinant inbred line population derived from 'G2333 $x$ G1983' (Blair et al. 2009). Another anti-nutrient present in the french bean is condensed tannins, Caldas et al. 2009 mapped 12 QTLs controlling the trait from three intergene pool populations. It was concluded that tannins follow oligogenic inheritance and genes controlling seed coat colour and pattern are responsible for tannin accumulation. The QTLs for anti-nutrient traits would be instrumental in their genetic removal and bioavailability of important vitamins and minerals.

\section{Biotic Stress}




\section{Disease resistance}

There are about $50 \mathrm{spp}$ of fungi, virus and bacteria which cause economic losses in the bean production (Sofkova et al. 2010). Integrated disease management viz. resistant cultivars, cultural control, mechanical control and chemical control is required for reducing the attack of these pathogens. Among all this, the use of resistant varieties is promising for inhibiting the invasion of pathogens due to its eco-friendly and efficient approach. Development of resistant cultivars is the primary objective of all the breeding institutes and various resistant varieties, advanced lines and QTLs are found against economically essential pathogens. The major diseases of French bean are powdery mildew (Erysiphe polygoni), black rot (Thielaviopsis basicola), Fusarium rot (Fusarium solani sp. phaseoli), Pythium blight (Pythium spp), Rhizoctonia rot (Rhizoctonia solani), white mold (Sclerotinia sclerotiorum), Angular leaf spot, ALS (Phaeiosariopsis griseola, Phg), rust (Uromyces appendiculatus), bean common mosaic virus (BCMV), bean yellow mosaic virus (BYMV), Bean golden mosaic virus (BGMV), Southern bean mosaic virus (SBMV), Bean curly top virus (BCTV), pod mottle virus (PMV) and root-knot nematode. The mapping of traits related to disease resistance revealed new gene clusters and QTLs imparting resistance against the pathogens.

\section{Fungal diseases}

Anthracnose (Colletotrichum lindemuthianum) is a cosmopolitan and seed-borne disease found mostly in all continents. The initial symptoms are found on aerial parts possessing lesions having conidial mass which are capable of disseminating and causing an infection on healthy plants. About 100 races of the pathogen are found worldwide (Sicard et al. 1997) and the monogenic genes governing resistance are located on Co-1 to Co-10. Among these, the multiple resistance alleles exist at Co-1,3,4 and 9 (Mendez-Vigo et al. 2005). The chromosomes having significant QTLs for resistance were Pv01, 02, 04, whereas the minor QTLs on Pv10 and Pv11 and it was reported that the resistance was conditioned by Co-1 gene that mapped on Pv01 (Zuiderveen et al. 2016).

ALS (Phaeoisariopsis griseola (Sacc) Ferraris is a severe disease which affects the aerial parts of plant, i.e. seeds, pods, petioles and leaflets are resulting into premature leaf dropping and necrosis which reduces the quality of seed. This disease is governed mainly by dominant genes (Mahuka et al. 2004), but monogenic recessive genes also support the resistance in some cases (Correa et al. 2001). Various SCAR or RAPD markers linked with dominant genes were reported (Miklas et al. 2006). SCAR marker (SN02) was found linked with Phg-2 gene (Sartorato et al. 2000), which cosegregated with resistance gene (dominant) in Cornell 49-242 (Nietsche et al. 2000). Information regarding five QTLs was obtained from the crossing of DOR 364 and G19833, which was found linked with B4 and B10 groups (Lopez et al. 2003). These QTLs were having a similar structure with R genes and were found to reside within clusters of the gene as resistance to disease co-located with three QTLs. But these QTLs were not fully explored for breeding purposes.

White mold (Sclerotinia sclerotiorum) attack aerial parts of plant and lesions are found on leaves, pods, branches and stems. These lesions are circular and dark green with water-soaked appearance which increases in size at later stages, and the entire organs are killed. A total of 27 QTLs were found for physiological resistance, and about 36 QTLs coalesced with 18 regions of the genome for avoidance traits (Schwartz and Singh 2013). Identification of meta-QTL imparting 
partial resistance against white mold concluded that 37 QTLs were present across fourteen recombinant inbred bi-parental populations. Out of these 37 QTLs, nine were identified as metaQTL WM 1.1, 2.2, 3.1, 5.4, 6.2, 7.1, 7.4, 7.5 and 8.3 (Vasconcellos et al. 2017).

Root rot is caused by complex of various pathogens including Fusarium spp, Rhizoctonia spp, Pythium spp, Macrophomina spp, Thielaviopsis spp and Aphanomyces spp (Abawi \& PastorCorrales 1990). About 4 QTLs having minor effect were found in Dorado/XAN 176 population (Miklas et al. 1998b) and two QTLs showing more substantial effect were located on the linkage groups B4 and B7 (Miklas et al. 2000c). About 30 QTLs, showing minor effect were reported from the RIL populations of four different resistance sources. In case of Fusarium root rot, 16 QTLs were identified from a RIL population of Montcalm $\times$ FR266 (Schneider et al. 2001), 2 QTLs were reported from RIL population of AC Compass $\times$ NY2114-12 (Chowdbury et al. 2002), and 6 QTLs were identified from RIL population of Eagle $\times$ Puebla 152 (Navarro et al. 2003). In comparison to other pathogens of root rot, the study and identification of QTLs and resistance genes is more in case of Fusarium spp (Cross et al. 2000)

\section{Bacterial diseases}

BB (Xanthomonas axonopodis pv. phaseoli) is a seed-borne disease of common bean that decreases its production worldwide. The symptoms are found on leaves, having leaf spots which further coalesce causing leaf blight and also invade vascular tissues and infects pods, seeds and stems. The breeding for resistance is difficult due to identification of 24 QTLs that are distributed among all 11 chromosomes or linkage groups, and the influence of environment expresses these QTLs, plant maturity, disease pressure and infected organs of the plant, making this process more complex (Yu et al. 2012). The source of significant QTLs or resistance gene is tepary bean cultivars viz., PI319443, G40001 and PI 44079. Since tepary bean possesses high resistance against BB, so efforts for transferring the genetic factors from tepary to common bean was practised through interspecific hybridizations (Singh and Munoz 1999). The three crucial QTLs located on B6,8 and 10 were linked with the SCAR markers BC420, SU91 and SAP6, respectively (Kelly et al. 2003) and these were used for MAS of BB resistance (Yu et al. 2000).

HB (Pseudomonas syringae pv. phaseolicola) is also a seed-borne disease attacking the bean foliage and pods. The yield loss by BB and HB ranges from 30-100 per cent, mostly due to adverse climatic conditions which persist at early growth stages (Schwartz et al. 2001). About nine pathogen races (Psp 1 to Psp 9) were reported based on cultivars reactions to these races (Taylor et al. 1996a). The QTLs for HB resistance were reported from the similar gene cluster as observed for anthracnose (Geffroy et al. 2000). The three QTLs from RIL population (BelNeb-RR-1 × A55) corresponded with the location of Pse-1, 3 and 4 genes on B4, 2 and 4 linkage groups, respectively (Fourie et al. 2004).

\section{Viral diseases}

Viruses are the serious pathogens of common bean and are responsible for yield reduction, worldwide (Sofkova et al. 2010). The critical viral diseases of the common bean are BCMV, BGMV, BCTV, SBMV and PMV. The major QTLs conditioning mosaic resistance resides in the gene clusters i.e. Ur-5, Pse-1 and Co-9 on B4 (Miklas et al. 1996b) and the QTLs imparting resistance to BCTV, BB, anthracnose, white mold and Macrophomina are located on B7. The amplification of different fragment size from the linkage of primers for SW12 SCAR (Singh et al. 
2000a) with the BGYMV QTL located on B4 was reported to cosegregate codominantly with Co9 gene (Mendez-Vigo et al. 2005) and hence supporting the presence of BGYMV-resistance QTL on B4 resistance gene cluster. The SW12.700 SCAR linked with B4 QTL and SR2 SCAR marker linked with bgm-1 gene (Urrea et al. 1996) were reported to be the only genes found to date imparting resistance against BGYMV amenable to MAS (Lopez et al. 2003).

\section{Insect and nematode resistance}

Insects and nematodes cause severe loss (35-100 per cent) to the quality and yield of snap beans and dry beans depending on the severity of pest (Singh and Schwartz 2011). These pests attack both aerial as well as underground parts of the french bean (Singh 2001; Cardona and Kornegay 1999). In comparison to diseases, like bean mosaic and bacterial blight that are distributed widely, most insects and nematodes have regional importance. The important insect pests of French bean are leafhoppers (Empoasca spp), Thrips (Thrips spp), whitefly (Bemisia tabaci), weevils (Apion spp), Bean fly (Ophiomyia phaseoli), pod borer (Maruca spp), aphid (Aphis fabae), chrysomelid (Ootheca spp), bruchids (Zabrotes spp) and mites (Tetranychus spp) (Schwartz and Peairs 1999). Insects are also important vectors of bean viruses i.e BCMV, BYMV (transmitted by aphids), BGMV, BGYMV (transmitted by whitefly) and BCTV (transmitted by leafhoppers). The resistant QTLs and genes are present in various wild and cultivated populations in the different gene pools of the French bean. Resistance to Empoasca spp from a RIL population (EMP $419 \times$ Berna Dutch brown) was quantitative to leaf burn and leaf curl that was controlled by QTLs on linkage group B7 and B1 (Murray et al. 2004a). Resistance to thrips from a RIL population (BAT $881 \times$ G 21212) was quantitative, and major QTLs were identified on linkage groups B2, B3, B6 and B8 (Frei et al. 2005)

The distribution, occurrence and losses in french bean due to nematodes is poorly documented. The nematodes of economic importance to French bean are root-knot nematode (Meloidogyne spp), lesion nematode (Pratylenchus spp) and soybean cyst nematode (Heterodera glycines). The continuous use of susceptible cultivars exacerbates the population of nematodes and further rotation with susceptible crops like potato, tomato and pepper creates a serious problem for succeeding crop of French bean (Abawi and Widmer 2000, Schwartz et al. 2005).

Table 1. QTL mapping studies for biotic stresses in French bean.

\begin{tabular}{|c|c|c|c|c|}
\hline $\begin{array}{l}\text { Biotic } \\
\text { stress }\end{array}$ & QTL/markers & $\begin{array}{l}\text { Mapping population and } \\
\text { name of parents }\end{array}$ & Trait of interest & Reference \\
\hline \multirow[t]{6}{*}{$\begin{array}{l}\text { Fungal } \\
\text { diseases }\end{array}$} & $\begin{array}{l}\text { QTL:ER3 }{ }^{\mathrm{XC}}(\mathrm{LG} 3), \\
\text { SV6 } \\
\text { 1(LG7)(LG6), Py- }\end{array}$ & Xana and Cornell 49242 & Pythium root rot & $\begin{array}{l}\text { Campa et al. } \\
2010\end{array}$ \\
\hline & $\begin{array}{l}\text { QTL } \quad \text { FRR3.1 }{ }^{\mathrm{km}} \\
\text { (Pv03), LGs B2 and B3 }\end{array}$ & $\begin{array}{l}\text { K132 } \times \text { MLB-49-89A } \\
\text { K20 } \times \text { MLB-49-89A }\end{array}$ & Fusarium & $\begin{array}{l}\text { Kamfwa et al. } \\
2013\end{array}$ \\
\hline & $\begin{array}{l}\text { ME1 and BM211 } \\
\text { markers }\end{array}$ & $\mathrm{F}_{2}(\mathrm{CNFC} 9506$ and RP-2) & White mold resistance & Lara et al. 2014 \\
\hline & QTL- CoPv09c $c^{453-c}$ & SEL1308 $\times$ MDRK & Anthracnose & $\begin{array}{l}\text { Campa et al. } \\
2014\end{array}$ \\
\hline & $\begin{array}{l}7 \text { QTLs for various } \\
\text { traits }\end{array}$ & $\begin{array}{l}\text { RILs (RR6950 } \\
\text { OSU5446) }\end{array}$ & $\begin{array}{l}\text { Root rot resistance and } \\
\text { root traits }\end{array}$ & $\begin{array}{l}\text { Hargerty et al. } \\
2015\end{array}$ \\
\hline & $\begin{array}{l}\text { Phvul.005G117900 } \\
\text { candidate gene }\end{array}$ & $\begin{array}{l}\text { RILs (PMB0225 } \\
\text { PHA1037) }\end{array}$ & Anthracnose resistance & $\begin{array}{l}\text { González et } \\
\text { al. } 2015\end{array}$ \\
\hline
\end{tabular}




\begin{tabular}{|c|c|c|c|c|}
\hline & $\begin{array}{ll}\text { QTL: } & \text { Pv04, } \\
\text { Pv10(ALS10.1) } & \text { Phg1, } \\
\text { Phg2 } & \end{array}$ & $\begin{array}{l}\text { RILs (CAL } 143 \times \text { IAC- } \\
\text { UNA) }\end{array}$ & $\begin{array}{l}\text { Angular leaf spot } \\
\text { (Phaeoisariopsis) }\end{array}$ & $\begin{array}{l}\text { Oblessuc et al. } \\
2015\end{array}$ \\
\hline & $\begin{array}{l}\text { QTL: } \\
\text { Pv01,Pv02,Pv04,Pv10, } \\
\text { Co-1,Co-2 }\end{array}$ & $\mathrm{F}_{4: 6}$ RIL population & $\begin{array}{l}\text { Anthracnose } \\
\text { (Colletotrichum) }\end{array}$ & $\begin{array}{l}\text { Zuiderveen et } \\
\text { al. } 2016\end{array}$ \\
\hline & $\begin{array}{l}\text { KASP SS68 marker } \\
\text { associated with Pv11 }\end{array}$ & $\begin{array}{l}\text { Pinto } 114 \text { (susceptible) } \times \\
\text { Aurora (resistant with Ur- } \\
\text { 3) }\end{array}$ & Rust (Uromyces) & $\begin{array}{l}\text { Hurtado- } \\
\text { Gonzales et al. } \\
2017\end{array}$ \\
\hline & $\begin{array}{l}\text { QTLs } \\
\text { ALS11 }{ }^{\text {AS },} \quad \text { PWM2 }^{\text {AS }}, \\
\text { PWM11 }\end{array}$ & RILs (AND $277 \times$ SEA 5 ) & $\begin{array}{l}\text { powdery mildew } \\
\begin{array}{l}\text { angular leaf } \\
\text { resistance }\end{array}\end{array}$ & $\begin{array}{l}\text { Bassi et al. } \\
2017\end{array}$ \\
\hline & $\begin{array}{l}\text { QTLs WM1.1, WM2.2, } \\
\text { WM3.1, } \\
\text { WM6.2, WM5.4, } \\
\text { WM7.4, WM7.5, and } \\
\text { WM8.3. }\end{array}$ & 14 RILs & White mold resistance & $\begin{array}{l}\text { Vasconcellos } \\
\text { et al. } 2017\end{array}$ \\
\hline $\begin{array}{l}\text { Bacterial } \\
\text { diseases }\end{array}$ & $\begin{array}{l}3 \text { QTL } \\
\text { (AFLP, RAPD, RFLP } \\
\text { and SSR markers) }\end{array}$ & $\begin{array}{l}\text { OAC Seaforth } \times \text { OAC 95- } \\
4 \text { (SP) }\end{array}$ & $\begin{array}{l}\text { Common } r \text { bacterial } \\
\text { blight (Xanthomonas } \\
\text { axonopodis } \\
\text { Phaseoli) }\end{array}$ & $\begin{array}{l}\text { Tar-an et al. } \\
2001\end{array}$ \\
\hline & $\begin{array}{l}\text { LG02 QTL } \\
\text { (RAPD marker) }\end{array}$ & Belneb RR-1 × A-55 (RIL) & $\begin{array}{l}\text { Bacterial brown spot } \\
\text { (Pseudomonas } \\
\text { syringae pv. syringae) }\end{array}$ & $\begin{array}{l}\text { Jung et al. } \\
2003\end{array}$ \\
\hline & $\begin{array}{l}\text { QTL: BC420 (Pv06), } \\
\text { SU91(Pv08), } \\
\text { Xa11.4OV1 (Pv11) }\end{array}$ & $\begin{array}{l}\text { Teebus-BC5 (BBSS) } \times \\
\text { 'Teebus' (bbss) }\end{array}$ & $\begin{array}{l}\text { Common blight } \\
\text { (Xanthomonas) }\end{array}$ & $\begin{array}{l}\text { Miklas et al. } \\
2017\end{array}$ \\
\hline & $\begin{array}{l}\text { Quantitative:Pse-1, } \\
\text { Pse-2, Pse-3, Pse-4, } \\
\text { Pse-6, HB5.198BB, } \\
\text { 98LFA, } \\
\text { 96BBS }\end{array}$ & $\begin{array}{l}\text { RILs }(\text { SOA-BN } \times \text { Edmund } \\
\text { SE) } \\
\text { Canadian Wonder } \times \text { PI } \\
150414(\mathrm{CP}) \\
\text { and Rojo } \times \text { CAL } 143(\mathrm{RC})\end{array}$ & $\begin{array}{ll}\text { Halo } & \text { blight } \\
\text { (Pseudomonas }) & \end{array}$ & $\begin{array}{l}\text { Tock et al. } \\
2017\end{array}$ \\
\hline $\begin{array}{l}\text { Viral } \\
\text { diseases }\end{array}$ & $\begin{array}{l}\text { Qualitative: bc-1, bc-2, } \\
\text { bc-3 }\end{array}$ & $\begin{array}{l}\text { DOR364 × G19833 } \\
\text { Olathe } \times \text { Sierrra }\end{array}$ & $\begin{array}{ll}\text { Bean common mosaic } \\
\text { virus and } & \text { Mosaic } \\
\text { necrosis virus } & \\
\end{array}$ & $\begin{array}{l}\text { Strausbaugh et } \\
\text { al. } 1999\end{array}$ \\
\hline & $\begin{array}{l}\text { Qualitative, } \\
\text { quantitative, Bgm-1, } \\
\text { RNA }\end{array}$ & DOR476 $\times$ SEL1309 & $\begin{array}{l}\text { Bean golden yellow } \\
\text { mosaic virus }\end{array}$ & $\begin{array}{l}\text { Blair et al. } \\
2007\end{array}$ \\
\hline & $\begin{array}{l}974 \text { kb portion on } \\
\text { chromosome } 2 .\end{array}$ & RILs (B-21 x Hstyle) & Potyvirus Resistance & Hart et al. 2015 \\
\hline $\begin{array}{l}\text { Insect } \\
\text { pests }\end{array}$ & $\begin{array}{l}\text { Quantitative:Chr2(b01) } \\
\text {, Chr3(b08), Chr4(b07), } \\
\text { Chr6(b11) }\end{array}$ & - & $\begin{array}{l}\text { Bean pod weevil } \\
(\text { A.goodmani) }\end{array}$ & 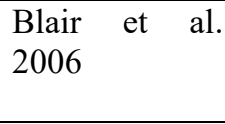 \\
\hline & $\begin{array}{l}\text { QTL: Pv01, } \quad \text { Pv02, } \\
\text { Pv03, Pv06, } \\
\text { Pv07, } \\
\text { Pv08, Pv09 }\end{array}$ & Matterhorn*/EMP507 & $\begin{array}{l}\text { Leafhopper }(E . \\
\text { kraemeri and E. Fabae })\end{array}$ & Brisco 2012 \\
\hline & $\begin{array}{l}\text { QTL: Pv01, Pv03 and } \\
\text { Pv07 }\end{array}$ & $\begin{array}{l}\text { EMP } 419 \times \text { Berna Dutch } \\
\text { brown }\end{array}$ & $\begin{array}{l}\text { Leafhopper }(E . \\
\text { kraemeri and E. Fabae })\end{array}$ & $\begin{array}{l}\text { Murray et al. } \\
2004\end{array}$ \\
\hline
\end{tabular}

\section{Abiotic stresses}


Environment plays a very crucial role in the development of plants; all the edaphic and climatic factors run parallel during the growth to bring the crop to maturity. During the course of time, deficiency or excess or any environmental factor causes severe yield constraints. Drought stress is a major limitation in yield potential of French bean, especially in subtropical and tropical regions (Rao 2014). Southern Africa and Central America face severe challenges of drought stress in 60 per cent of areas periodically (Ambachew et al. 2015; Darkwa et al. 2016). The significant traits controlling resistance to drought include root depth and size, phenology, carbohydrate mobilization and storage, root hydraulic conductivity and efficiency of water absorption (Beebe et al. 2013). The focus of breeders is primarily gained by food mobilization traits from source to sink during drought stress (Rao et al. 2017). The food mobilizing traits are harvest index, pod harvest index and pod partitioning index (Beebe et al. 2013) which are regarded as a tool for selecting drought resistance beans (Polania et al. 2016; Polania et al. 2017). As most of the stresses, the drought resistance traits are also highly influenced by environment and inherited quantitatively (Mir et al. 2012). The QTLs for resistance to drought have been mapped in various sources (Table 2) for exploitation in marker-assisted breeding programs (Schneider et al. 1997; Chavarro and Blair 2010; Asfaw et al. 2012; Blair et al. 2012; Mukeshimana et al. 2014; Trapp et al. 2015; Briñez et al. 2017)

Heavy metal toxicity such aluminium $(\mathrm{Al})$ and manganese $(\mathrm{Mn})$ result in elevated levels of acidity in the soil which is problematic in bean productivity especially in Africa and Latin America (Rao et al. 2016). There is the interaction of stresses among each other, as acid soils reduce root growth, thus lead to drought stress posing yield challenges (Yang et al. 2013). Al toxicity resistance was identified using root traits such as primary root elongation rate, length of roots, and higher diameter of roots in the Andean gene pool (Blair et al. 2009) and QTLs for Al toxicity tolerance were identified by López-Marín and Rao (2009).

Soils with low phosphorus (P) are unfit for breaking yield ceiling of French bean in tropical regions (Beebe 2012). Most of the areas around the globe have low P soils stimulating severe yield constraints as artificial incorporation of phosphorus is not cost-effective (Nielsen et al. 2001). Traits fighting against low soil $\mathrm{P}$ include more considerable root length, $\mathrm{P}$ uptake efficiency and root area (Ochoa et al. 2006; Rao et al. 2016). Greater P uptake efficiency is obtained by roots foraging the topsoil through root morphological traits (Lynch 2011). QTLs linked to root traits enhancing P uptake has been identified for validation and introgression (Beebe et al. 2006; Ochoa et al. 2006; Cichy et al. 2009a).

French bean grows well under an optimum range of temperature $\left(14-30^{\circ} \mathrm{c}\right)$ and day temperature more than 30 degrees or night temperature above 20 degrees is detrimental in bean productivity (De Ron et al. 2016). Blossom drop is major problem due to high temperature triggered by pollen sterility as a result of which fewer seeds are produced. Transpiration cooling is achieved by diffusion of carbon dioxide through the stomatal opening at elevated air temperatures (Porch and Hall 2013). Bean genotypes capable of opening stomata at high temperature are valuable sources of resistance to heat stress (Prasad et al. 2017). Therefore, more significant thermal cooling under stress conditions could be a pathway for mapping QTLs for heat stress (McClean et al. 2011; Deva et al. 2020). 
French bean is equally sensitive to drop in temperature than usual air temperature required for its growth, especially in early growth stages (Meyer and Badaruddin 2001). A total of 50 per cent rate of mortality was reported at a temperature below freezing temperature $\left(-3.25^{\circ} \mathrm{C}\right)$ and limited growth after survival. The sources of resistance to low temperature can serve as a valuable material for QTL mapping in French bean (Souter et al. 2017; Rodino et al. 2007)

Table 2. QTL mapping studies for abiotic stresses in French bean.

\begin{tabular}{|c|c|c|c|}
\hline Molecular maker/QTL & Source & Trait/objective & Reference \\
\hline 5 RAPD markers & $\begin{array}{l}\text { RILs [Sierra } \times \text { AC1028 } \\
(\mathrm{S} / \mathrm{A}), \text { Sierra } \times \text { Lef-2RB } \\
(\mathrm{S} / \mathrm{L})]\end{array}$ & Drought tolerance & $\begin{array}{l}\text { Schneider et al. } \\
1997\end{array}$ \\
\hline $\begin{array}{l}36 \text { QTL for various traits, } \\
\text { QTLs on b01 near fin locus }\end{array}$ & RILs $($ A55 × G122) & $\begin{array}{l}\text { phenological, architectural and } \\
\text { yield traits under abiotic stress }\end{array}$ & $\begin{array}{l}\text { Chavarro and } \\
\text { Blair } 2010\end{array}$ \\
\hline 9 QTLs on 6 linkage groups & $\begin{array}{l}\text { RILS ( DOR364 } \times \\
\text { BAT477) }\end{array}$ & $\begin{array}{l}\text { photosynthate acquisition, } \\
\text { accumulation, and } \\
\text { remobilization under drought }\end{array}$ & $\begin{array}{l}\text { Asfaw et al. } \\
2012\end{array}$ \\
\hline 15 QTLs on 5 linkage groups & $\begin{array}{l}\text { RILs (DOR364 } \quad \times \\
\text { BAT477) }\end{array}$ & Drought tolerance & Blair et al. 2012 \\
\hline $\begin{array}{l}\text { QTLs i.e. SY1.1, SY2.1, } \\
\text { PW1.2 BR, NDVI 1.1 BR }\end{array}$ & RILs (Buster $\times$ Rosa) & Drought tolerance & $\begin{array}{l}\text { Trapp et al. } \\
2015\end{array}$ \\
\hline $\begin{array}{l}\text { QTLs SW, QTL SY3.3SC on } \\
\text { Pv03, } 14 \text { other QTLs }\end{array}$ & RILs (SEA5 and CAL96) & Drought tolerance & $\begin{array}{l}\text { Mukeshimana } \\
\text { et al. } 2014\end{array}$ \\
\hline $\begin{array}{l}22 \text { QTLs linked to drought } \\
\text { tolerant traits }\end{array}$ & $\mathrm{F}_{8}($ SEA $5 \times$ AND 277$)$ & Drought tolerance & $\begin{array}{l}\text { Briñez et al. } \\
2017\end{array}$ \\
\hline QTLs on Pv01,04,08 & $\begin{array}{llll}\text { RILs (BAT } & 881 & \times \\
\text { G21212) } & & \\
\end{array}$ & Abiotic stresses & Diaz et al. 2018 \\
\hline Pleiotropic QTLs on pv10 & $\begin{array}{l}\text { RILs (BRB } 191 \times \text { SEQ } \\
\text { 1027) }\end{array}$ & Drought tolerance & $\begin{array}{l}\text { Nabateregga } \\
\text { et al. } 2019\end{array}$ \\
\hline $\begin{array}{l}\text { QTLS Df1.1, Df 1.2, Dp1.1, } \\
\text { Sp2.1, Wp1.1, Wp5.1, Syp1.1, } \\
\text { Syp1.2, Sp2 }\end{array}$ & $\begin{array}{l}\text { RILS (Tiber } \\
\text { Starozagorski čern ) }\end{array}$ & Drought tolerance & $\begin{array}{l}\text { Sedlar et al. } \\
2020\end{array}$ \\
\hline $\begin{array}{l}2 \text { major QTLs on B2 and B9, } \\
17 \text { minor QTLs }\end{array}$ & RILs (G2333 × G19839) & $\begin{array}{l}\text { adventitious root traits under low } \\
\mathrm{P}\end{array}$ & $\begin{array}{l}\text { Ochoa et al. } \\
2006\end{array}$ \\
\hline 26 QTLs & $\begin{array}{l}\text { RILs } \\
364)\end{array} \quad($ G19833 $\times$ DOR & $\begin{array}{l}\text { Root architecture traits under } \\
\text { low } \mathrm{P}\end{array}$ & $\begin{array}{l}\text { Beebe et al. } \\
2006\end{array}$ \\
\hline QTLs linked to fin gene & $\begin{array}{l}\text { RILs (G19833 and } \\
\text { AND696) }\end{array}$ & $\begin{array}{l}\text { Root architecture traits and low } \\
\text { P tolerance }\end{array}$ & $\begin{array}{l}\text { Cichy et al. } \\
2009 \text { a }\end{array}$ \\
\hline 24 QTLs & \begin{tabular}{|l} 
RILs (DOR364 \\
G19833)
\end{tabular} & $\begin{array}{l}\text { Root morphology traits in } \mathrm{Al} \\
\text { toxicity }\end{array}$ & $\begin{array}{l}\text { López-Marín } \\
\text { and Rao } 2009\end{array}$ \\
\hline
\end{tabular}

\section{Future prospects}

The number of QTL mapping studies for biotic, abiotic and biofortification traits have been conducted, among which, mostly retain QTLs specific to a population or environment. To accelerate the desirable genotype development in ever-changing climatic conditions, one needs 
more stable QTLs. The QTLs which express under varying environmental conditions, less epistatic to background genotype for their efficient marker-assisted backcross breeding programs. The concept of mega-QTLs is one of crucial strategy for overcoming the problem and extensive utilization of QTLs among distinct backgrounds. The mapping studies are not entirely accomplished until the product is not utilized in developing sustainable genotype. There is an urgent need of broad collaborative testing of genotypes and QTLs among institutions and countries for validation and deployment in cultivars which is the ultimate goal of plant breeding. The information regarding the genetic basis of inheritance determined by previous studies is useful for improvement of French bean important. The powerful progression opens brand new research perspectives about the dynamics of combining different traits in one breeding program. This info is going to be helpful for the French bean breeders to choose a suitable technique for the inheritance analysis of quantitative characteristics and determining the novel genes in germplasm assets.

\section{References}

Abawi GS, Pastor-Corrales MA (1990) Root rots of beans in Latin America and Africa: Diagnosis, research methodologies, and management strategies. Centro Internacional de Agricultura Tropical (CIAT), Cali, Colombia, 114 p.

Abawi GS, Widmer TL (2000) Impact of soil health management practices on soil borne pathogens, nematodes and root diseases of vegetable crops. Appl Soil Ecol 15:37-47.

Ambachew D, Mekbib F, Asfaw A, Beebe SE, Blair MW (2015) Trait relations in common bean genotypes grown under managed-stress for drought and field infestation of bean fly. The Crop Journal 3:305-316

Asfaw A, Blair MW, Struik PC (2012) Multienvironment quantitative trait loci analysis for photosynthate acquisition, accumulation, and remobilization traits in common bean under drought stress. G3 2:579-595

Astudillo-Reyes C, Fernandez AC, Cichy KA (2015) Transcriptome characterization of developing bean (Phaseolus vulgaris 1.) pods from two genotypes with contrasting seed zinc concentrations. PLoS ONE 10(9): e0137157. https://doi.org/10.1371/journal.pone.0137157

Beaver JS, Osorno JM, Ferwerda FH, Muñoz Perea CG (2005) Registration of bean golden yellow mosaic virus resistant germplasms PR9771-3-1, PR0247-49 and PR0157-4-1. Crop Sci 45:2126

Beebe S, Skroch P, Tohme J, Duque MC, Pedraza F, Nienhhuis J (2000) Structure of genetic diversity among common bean landraces of middle American origin based on correspondence analysis of RAPD. Crop Sci 40:264-273

Beebe SE (2012) Common bean breeding in the tropics. Plant Breed Rev 36:357-426

Beebe SE, Rao IM, Blair MW, Acosta-Gallegos JA (2013) Phenotyping common beans for adaptation to drought. Front Physiol doi 4. https://doi.org/10.3389/fphys.2013.00035 
Beebe SE, Rojas-Pierce M, Yan X, Blair MW, Pedraza F, Muñoz F, Tohme F, Lynch JP (2006) Quantitative trait loci for root architecture traits correlated with phosphorus acquisition in common bean. Crop Sci 46:413-423

Blair MW (2013) Mineral Biofortification Strategies for Food Staples: The Example of Common Bean. J Agric Food Chem 61: 8287-8294.

Blair M W, Astudillo C, Grusak M, Graham R, Beebe S (2009) Inheritance of seed iron and zinc content in common bean (Phaseolus vulgaris L.). Mol Breed 23:197-207. doi: 10.1007/s11032$008-9225-\mathrm{z}$

Blair MW, Galeano CH, Tovar E, Muñoz-Torres MC, Velasco A, Beebe SE, Rao IM (2012) Development of a Mesoamerican intra-gene pool genetic map for QTL detection in a drought tolerant x susceptible common bean (Phaseolus vulgaris L.) cross. Mol Breed 29:71-88

Blair MW, Giraldo MC, Buendia HF, Tovar E, Duque MC (2006a) Microsatellite marker diversity in common bean (Phaseolus vulgaris L). Theor Appl Genet 113:100-109.

Blair MW, Giraldo MC, Buendía HF, Tovar E, Duque MC, Beebe SE (2006) Microsatellite marker diversity in common bean (Phaseolus vulgaris L.) Theor Appl Genet 113:100-109

Blair MW, Izquierdo P (2012) Use of the advanced backcross-QTL method to transfer seed mineral accumulation nutrition traits from wild to Andean cultivated common beans. Theor Appl Genet 125: 1015-1031. doi: 10.1007/s00122-012-1891-x

Blair MW, López-Marín HD, Rao IM (2009) Identification of aluminum resistant Andean common bean (Phaseolus vulgaris L.) genotypes. Brazil J Plant Physiol 21:291-300

Blair MW, Munoz C, Buendía HF, Flower J, Bueno JM, Cardona C (2010b) Genetic mapping of micro satellite markers around the arcelin bruchid resistance locus in common bean. Theor Appl Genet 121: 393-402.

Blair MW, Munoz C, Garza R, Cardona C (2006b) Molecular mapping of genes for resistance to the bean pod weevil (Apion godmani Wagner) in common bean. Theor Appl Genet 112:913-923.

Blair MW, Prieto S, Diaz LM, Buendia HF, Cardona C (2010a) Linkage disequilibrium at the APA-Arcelin insecticidal seed storage protein locus of common bean (Phaseolus vulgaris L.). BMC Plant Bio 10: 79.

Blair MW, Rodriguez LM, Pedraza F, Morales F, Beebe SE (2007) Genetic mapping of the bean golden yellow mosaic geminivirus resistance gene bgm-1 and linkage with potyvirus resistance in common bean (Phaseolus vulgaris L.). Theor Appl Genet 114:261-271.

Briñez B, Perseguini JM, Santa RJ, Bassi D, Ribeiro GG et al (2017) Mapping QTLs for drought tolerance in a SEA 5 x AND 277 common bean cross with SSRs and SNP markers. Genet Mol Biol 40:813-823

Brisco EI (2012) Empoasca leafhopper species resistance in common bean, Phaseolus vulgaris: Field Screening and QTL Identification. Dissertation, Michigan State University, Plant Breeding, Genetics and Biotechnology Program/Crop and Soil Sciences. 
Broughton WJ, Hernandez G, Blair MW, Beebe SE, Gepts P, Vanderleyden J (2003) Beans (Phaseolus spp.) - model food legumes. Plant Soil 252: 55-128. doi: 10.1023/A:1024146710611

Caldas GV, Blair MW (2009) Inheritance of seed condensed tannins and their relationship with seed-coat color and pattern genes in common bean (Phaseolus vulgaris L.). Theor Appl Genet 119(1):131-142. DOI: 10.1007/s00122-009-1023-4.

Campa A, Perez-Vega E, Pascual A, Ferreira JJ (2010) Genetic analysis and molecular mapping of quantitative trait loci in common bean against Pythium ultimum. Phytopathol 100:315-320.

Cardona C, Kornegay J (1999) Bean germplasm resources for insect resistance. SL Clement and SS Quisenberry, eds. Global plant genetic resources for insect resistance. CRC Press, Boca Raton, FL. pp 85-99

Chavarro MC, Blair M W (2010) QTL analysis and effect of the fin locus on tropical adaptation in an inter-gene pool common bean population. Trop Plant Biol 3(4): 204218. doi:10.1007/s12042-010-9058-x

Chowdbury MA, Yu K, Park SJ (2002) Molecular mapping of root rot resistance in common bean. Annu Rep Bean Improv Coop 45:96-97.

Cichy KA, Blair MW, Galeano CH, Snapp SS, Kelly JD (2009a) QTL analysis of root architecture traits and low phosphorus tolerance in an Andean bean population. Crop Sci 49:59-68

Cichy KA, Caldas GV, Snapp SS, Blair MW (2009b) QTL analysis of seed iron, zinc, and phosphorus levels in an Andean bean population. Crop Sci 49: 1742-1750.

Correa RX, Good-God PI, Oliveira MLP, Niestche S, Moreira MA, Barros EG (2001) Heranca da resistencia a manchaangular do feijoeiro e identificacao de marcadores moleculares flanqueando o loco de resistencia. Fitopatol Bras 26:27-32.

Cross H, Brick MA, Schwartz HF, Panella LW, Byrne PF (2000) Inheritance of resistance to Fusarium wilt in two common bean races. Crop Sci 40:954-958.

Darkwa K, Ambachew D, Mohammed H, Asfaw A, Blair MW (2016) Evaluation of common bean (Phaseolus vulgaris L.) genotypes for drought stress adaptation in Ethiopia. Crop J 4: 367-376

De Ron AM, Rodiño AP, Santalla M, González AM, Lema MJ, Martín I et al (2016) Seedling emergence and phenotypic response of common bean germplasm to different temperatures under controlled conditions and in open field. Front Plant Sci 7:1087. https://doi.org/10.3389/fpls.2016.01087

Deva CR, Urban MO, Challinor AJ, Falloon P, Svitákova L (2020) Enhanced leaf cooling is a pathway to heat tolerance in common bean. Front Plant Sci 11. doi:10.3389/fpls.2020.00019

Fourie D, Miklas PN, Ariyarathne HM (2004) Genes conditioning halo blight resistance to races 1, 7, and 9 occur in a tight cluster. Annu Rep Bean Improv Coop 47:103-104. 
Frei A, Blair MW, Cardona C, Beebe SE, Gu H, Dorn S (2005) QTL mapping of resistance to Thrips palmi Karny in common bean. Crop Sci 45:379-387.

Geffroy V, Sevignac M, De Oliveira J, Fouilloux G, Skroch P, Thoquet P, Gepts P, Langin T, Dron M (2000). In: heritance of partial resistance against Colletotrichum lindemuthianum in Phaseolus vulgaris and co-localization of QTL with genes involved in specific resistance. Mol Plant Micr Inter 13:287-296.

Gepts PF, Aragao JL, DeBarros E, Blair MW, Brondani R, Broughton W (2008) Genomics of Phaseolus Beans, a Major Source of Dietary Protein and Micronutrients in the Tropics. In: Moore P.H. and Ming R. (Eds.), Genomics of Tropical Crop Plants.113-143. Springer Publishing, New York, NY.

Hurtado-Gonzales OP, Valentini G, Gilio TS, Martins AM, Song Q, Pastor-Corrales MA (2017) Fine mapping of Ur-3, a historically important rust resistance locus in common bean. G3 7:557569.

Izquierdo P, Astudillo C, Blair MW et al (2018) Meta-QTL analysis of seed iron and zinc concentration and content in common bean (Phaseolus vulgaris L.). Theor Appl Genet 131:16451658 . https://doi.org/10.1007/s00122-018-3104-8

Jung G, Ariyarathne HM, Coyne DP, Nienhuis J (2003) Mapping QTL for bacterial brown spot resistance under natural infection in field and seedling stem inoculation in growth chamber in common bean. Crop Sci 43:350-357.

Kamfwa K, Mwala M, Okori P, Gibson P, Mukankusi C (2013) Identification of QTL for Fusarium root rot resistance in common bean. J crop improv 27:406-418.

Kelly JD, Gepts P, Miklas PN, Coyne DP (2003) Tagging and mapping of genes and QTL and molecular-marker assisted selection for traits of economic importance in bean and cowpea. Field Crops Res 82: 135-154.

Lopez CE, Acosta IF, Jara C, Pedraza F, Gaitan-Solis E, Gallego G, Beebe S, Tohme J (2003) Identifying resistance gene analogs associated with resistances to different pathogens in common bean. Phytopathol 93:88-95.

Lopez-Marín HD, Rao IM, Blair MW (2009) Quantitative trait loci for root morphology traits under aluminum stress in common bean (Phaseolus vulgaris L). Theor Appl Genet 119:449-458

Lynch JP (2011) Root phenes for enhanced soil exploration and phosphorus acquisition: tools for future crops. Plant Physiol 156:1041-1049. https://doi.org/10.1104/pp.111.175414

Mahuku G, Montoya C, Henriquez MA, Jara C, Teran H, Beebe S (2004) Inheritance and characterization of angular leaf spot resistance gene present in common bean accession G 10474

McClean PE, Burridge J, Beebe S, Rao IM, Porch TG (2011) Crop improvement in the era of climate change: an integrated, multi-disciplinary approach for common bean (Phaseolus vulgaris). Funct Plant Biol 38: 927-933. 10.1071/FP11102 
Mendez-Vigo B, Rodriguez-Suarez C, Paneda A, Ferreira JJ, Giraldez R (2005) Molecular markers and allelic relationships of anthracnose resistance gene cluster B4 in common bean. Euphytica 141: 237-245.

Meyer DW, Badaruddin M (2001) Frost tolerance of ten seedling legume species at four growth stages. Crop Sci 41:1838-1842. https://doi.org/10.2135/cropsci2001.1838

Miklas PN (2005) DNA markers (SCARS) linked with disease resistance traits in bean (Phaseolus vulgaris L.). http://www.ars.usda.gov/sp2UserFiles/Place/53540000/Miklas/SCARtable.pdf (accessed on 10.09.2014).

Miklas PN, Fourie D, Chaves B, Chirembe C (2017) Common bacterial blight resistance QTL BC420 and SU91 effect on seed yield, seed weight, and canning quality in dry bean. Crop Sci 57:802-811.

Miklas PN, Johnson E, Stone V, Beaver JS, Montoya C, Zapata M (1996b) Selective mapping of QTL conditioning disease resistance in common bean. Crop Sci 36:1344-1351.

Miklas PN, Kelly JD, Beebe SE, Blair WM (2006) Common bean breeding for resistance against biotic and abiotic stresses: from classical to MAS breeding. Euphytica 147:106-131.

Miklas PN, Stone V, Daly MJ, Stavely JR, Steadman JR, Bassett MJ, Delorme R, Beaver JS (2000c) Bacterial, fungal, and viral disease resistance loci mapped in a recombinant inbred common bean population ('Dorado'/XAN 176). J Am Soc Hort Sci 125:476-481.

Miklas PN, Stone V, Urrea CA, Johnson E, Beaver JS (1998b) Inheritance and QTL analysis of field resistance to ashy stem blight. Crop Sci 38:916-921.

Mir RR, Zaman-Allah M, Sreenivasulu N, Trethowan R, Varshney RK (2012) Integrated genomics, physiology and breeding approaches for improving drought tolerance in crops. Theor Appl Genet 125:625-645. https://doi.org/10.1007/s00122012-1904-9

Mukeshimana G, Butare L, Cregan PB, Blair MW, Kelly JD (2014) Quantitative trait loci associated with drought tolerance in common bean. Crop Sci 54:923-938. https://doi.org/10.2135/cropsci2013.06.0427

Murray JD, Michaels TE, Cardona C, Schaafsma AW, Pauls KP (2004a) Quantitative trait loci for leafhopper (Empoasca fabae and Empoasca kraemeri) resistance and seed weight in the common bean. Plant Breed 123:474-479.

Navarro F, Sass M, Nienhuis J (2003) Identification and mapping bean root rot resistance in a population of Mesoamerican $\times$ Andean origin. Annu Rep Bean Improv Coop 46:213-214.

Nielsen KL, Eshel A, Lynch JP (2001) The effect of phosphorus availability on the carbon economy of contrasting common bean (Phaseolus vulgaris L.) genotypes. J Exp Bot 52:329-339

Nietsche S, Borem A, Carvalho GA, Rocha RC, Paula TJ, Barros EG, Moreira MA (2000) RAPD and SCAR markers linked to a gene conferring resistance to angular leaf spot in common bean. J Phytopathol 148: 117-121. 
Oblessuc PR, Matiolli CC, Chiorato AF, Camargo LA, Benchimol-Reis LL, Melotto M (2015) Common bean reaction to angular leaf spot comprises transcriptional modulation of genes in the ALS10.1 QTL. Front Plant Sci 6:152.

Ochoa IE, Blair MW, Lynch JP (2006) QTL analysis of adventitious root formation in common bean (Phaseolus vulgaris L.) under contrasting phosphorus availability. Crop Sci 46:1609- 1621

Petry N, Boy E, Wirth JP, Hurrell RF (2015) The potential of the common bean (Phaseolus vulgaris) as a vehicle for iron biofortification. Nutrients 7:1144-1173. doi: 10.3390/nu7021144

Polania J, Rao IM, Cajiao C, Grajales M, Rivera M, Velasquez F, Raatz B, Beebe SE (2017) Shoot and root traits contribute to drought resistance in recombinant inbred lines of MD 23-24 $\times$ SEA 5 of common bean. Front Plant Sci 8(296):1-18. https://doi.org/10.3389/fpls.2017.00296

Polania J, Rao IM, Cajiao C, Rivera M, Raatz B, Beebe S (2016) Physiological traits associated with drought resistance in Andean and Mesoamerican genotypes of common bean (Phaseolus vulgaris L.). Euphytica 210:17-29. https://doi. org/10.1007/s10681-016-1691-5

Porch T, Hall A (2013) "Heat tolerance," in genomics and breeding for climate resilient crops. Ed: Kole C, Berlin, Springer. 2:167-195. 10.1007/978-3-642-37048-9_4

Prasad PV, Bheemanahalli R, Jagadish SK (2017) Field crops and the fear of heat stressopportunities, challenges and future directions. Field Crops Res. 200: 14-121. 10.1016/j.fcr.2016.09.024

Rao IM (2014) Advances in improving adaptation of common bean and Brachiaria forage grasses to abiotic stress in the tropics. In: Pessarakli M (ed) Handbook of plant and crop physiology. FL pp, Boca Raton, pp 847-889

Rao IM, Beebe SE, Polania J, Grajales M, Cajiao C, Ricaurte J, Garcia R, Rivera M (2017) Evidence for genotypic differences among elite lines of common bean in their ability to remobilize photosynthate to increase yield under drought. J Agric Sci 155:857-875. https://doi.org/10.1017 $\underline{\text { SO0021859616000915 }}$

Rao IM, Miles JW, Beebe SE, Horst WJ (2016) Root adaptations to soils with low fertility and aluminium toxicity. Ann Bot 118:593-605. https://doi.org/10.1093/aob/mcw073

Rodino AP, Lema EM, Marlene PB, Santalla M, De Ron AM (2007) Assessment of runner bean (Phaseolus coccineus L.) germplasm for tolerance to low temperature during early seedling growth. Euphytica 155:63-70. https://doi. org/10.1007/s10681-006-9301-6

Sachwartz HF, Peairs FB (1999) Integrated pest management: In: Common bean improvement in the twenty-first century (Singh SP ed). Kluwer Academic Press, Dordrecht, The Netherlands, pp 371-388.

Sachwartz HF, Singh SP (2013) Breeding common bean for resistance to white mold: A review. Crop Science 53 (5):1832-1844. 
Sartorato A, Nietsche S, Barros EG, Moreira MA (2000) RAPD and SCAR markers linked to resistance gene to angular leaf spot in common beans. Fitopatol Bras 25: 637-642.

Schneider KA, Brothers ME, Kelly JD (1997) Marker-Assisted Selection to Improve Drought Resistance in Common Bean. Crop Sci 37(1):51. doi:10.2135/cropsci1997.0011183x0037000100

Schneider KA, Grafton KF, Kelly JD (2001) QTL analysis of resistance to Fusarium root rot in bean. Crop Sci 41: 535- 542.

Schwartz HF, Brick MA, Nuland DS, Franc GD (2001) Dry bean production and pest management, Regional Bulletin No. 562A. Colorado State University Extension and Agricultural Experiment Station, Fort Collins, Colorado.

Schwartz HF, Steadman JR, Hall R, Forster RL (2005) Compendium of bean diseases. 2nd ed. APS Press, St. Paul, MN. 109 pp.

Sedlar A, Zupin M, Maras M, Razinger J, Šuštar-Vozlič J, Pipan B, Meglič V (2020) QTL Mapping for drought-responsive agronomic traits associated with physiology, phenology, and yield in an andean intra-gene pool common bean population. Agronomy 10: 225.

Sicard D, Michalakis Y, Dron M, Neema C (1997) Genetic diversity and pathogenic variation of Colletotrichum lindemuthianum in the three centres of diversity of its host, Phaseolus vulgaris. Phytopathol 87: 807-813.

Singh SP (1991) Bean genetics. In: van Schoonhoven A, Voysest O (eds) Common beans: research for crop improvement. CAB International, Wallingford, pp 199-286

Singh SP (2001) Broadening genetic base of common bean cultivars: A review. Crop Sci 41: 16591675.

Singh SP, Morales FJ, Miklas PN, Teran H (2000a) Selection for bean golden mosaic resistance in intra- and inter-racial bean populations. Crop Sci 40:1565-1572.

Singh SP, Munoz CG (1999) Resistance to common bacterial blight among Phaseolus species and common bean improvement. Crop Sci 39: 80-89.

Singh SP, Sachwartz HF (2011) Review: Breeding common bean for resistance to insect pest and nematodes. Canadian J of P1 Sci 91:239-250.

Sofkova S, Poryazov I, Kiryakov I (2010) Breeding green beans (Phaseolus vulgaris L.) for complex disease resistance. Genetics and Breeding 38 (3):77-88.

Souter JR, Gurusamy V, Porch TG, Bett KE (2017) Successful introgression of abiotic stress tolerance from wild tepary bean to common bean. Crop Sci 57:1-12

Sperotto RA, Ricachenevsky FK (2017) Common bean fe biofortification using model species' lessons. Front Plant Sci 8:2187. doi: 10.3389/fpls.2017.02187 
Strausbaugh CA, Myers JR, Forster RL, McClean PE (1999) Bc-1 and Bc-u-two loci controlling bean common mosaic virus resistance in common bean are linked. J Amer Soc Hort Sci 124:644648.

Taran B, Michaels TE, Pauls KP (2001) Mapping genetic factors affecting the reaction to Xanthomonas axonopodis pv. phaseoli in Phaseolus vulgaris L. under field conditions. - Genome 44(6): 1046-1056.

Taylor JD, Teverson DM, Allen MA, Pastor-Corrales MA (1996a) Identification and origin of races of Pseudomonas syringae pv. phaseolicola from Africa and other bean growing areas. Plant Pathol 45:469-478.

Tock AJ, Fourie D, Walley PG, Holub EB, Soler A, Cichy KA, Pastor-Corrales MA, Song Q, Porch TG, Hart JP, Vasconcellos RCC, Vicente JG, Barker GC, Miklas PN (2017) Genome-wide linkage and association mapping of halo blight resistance in common bean to race 6 of the globally important bacterial pathogen. Front Plant Sci 8:1170.

Trapp JJ, Urrea CA, Cregan PB, Miklas PN (2015) Quantitative trait loci for yield under multiple stress and drought conditions in a dry bean population. Crop Sci 55:1596-1607

Urrea CA, Miklas PN, Beaver JS, Riley RH (1996) A codominant randomly amplified polymorphic DNA (RAPD) marker useful for indirect selection of BGMV resistance in common bean. J Am Soc Hort Sci 121: 1035-1039.

Vasconcellos RCC, Oraguzie OB, Soler A, Arkwazee H, Myers JR, Ferreira JJ (2017) Meta-QTL for resistance to white mold in common bean. PLoS ONE 12(2): e0171685.doi:10.1371/ journal.pone. 0171685

Yang Z, Rao IM, Horst WJ (2013) Interaction of aluminium and drought stress on root growth and crop yield on acid soils. Plant Soil 372:3-25. https://doi.org/10.1007/s11104-0121580-1

Yu K, Chun S, Zhang BL (2012) Development and application of molecular markers to breed common bean (Phaseolus vulgaris L.) for resistance to common bacterial blight (CBB)-current status and future directions. In: Applied Photosynthesis (Najafpour M ed). Shangai, China, pp 365388. http://cdn.intechopen.com/pdfs-wm/30614.pdf

Yu K, Park SJ, Poysa V (2000) Marker-assisted selection of common beans for resistance to common bacterial blight: Efficiency and economics. Plant Breed 119: 411-415.

Zuiderveen GH, Padder BA, Kamfwa K, Song Q, Kelly JD (2016) Genome-wide association study of anthracnose resistance in Andean beans (Phaseolus vulgaris). PLoS One 11: e0156391. https://doi.org/10.1371/journal.pone.0156391 